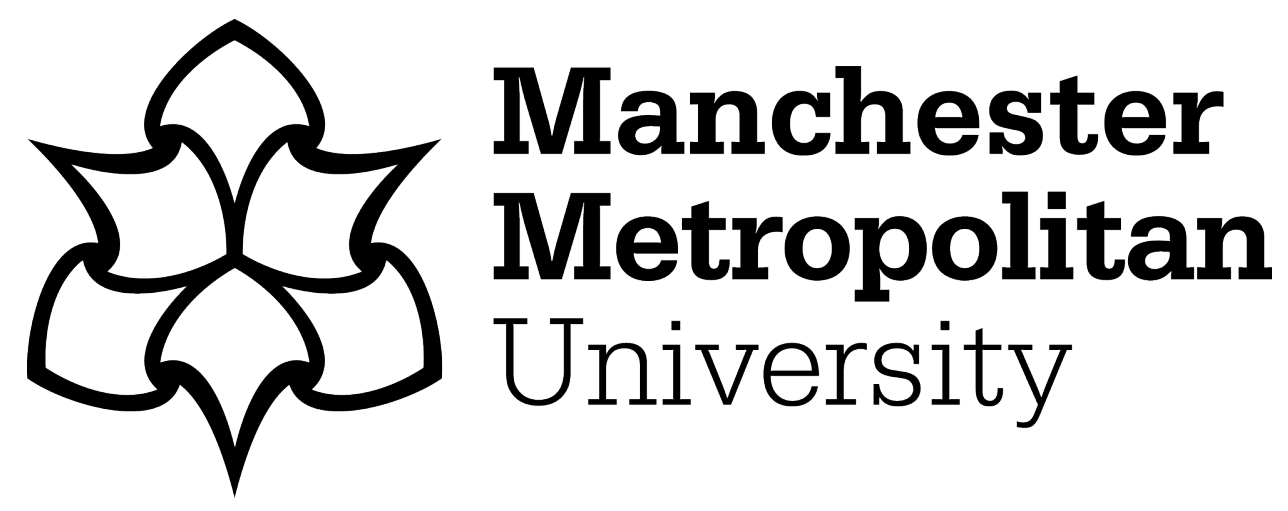

Hodgkinson, I, Hannibal, CL, Keating, B, Chester-Buxton, R and Bateman, N (2017) Towards a Public Service Management: Past, Present and Future Directions. Journal of Service Management, 28 (5). pp. 998-1023. ISSN 1757-5818

Downloaded from: https://e-space.mmu.ac.uk/620614/

Publisher: Emerald

DOI: https://doi.org/10.1108/JOSM-01-2017-0020

Please cite the published version 


\title{
Towards a Public Service Management: Past, Present, and Future Directions
}

\begin{abstract}
Purpose - In providing a fine grained analysis of public service management the review makes an important contribution to furthering research in service management, a body of literature that has tended to regard public services as homogenous or to neglect the context altogether.
\end{abstract}

Design/methodology/approach - Integrating public management and service management literatures, the past and present of public service management are discussed. Future directions for the field are outlined drawing on a service-dominant approach that has the potential to transform public services. Invited commentaries augment the review.

Findings - The review presents the Public Service Network Framework (PSNF) to capture the public value network in its abstraction and conceptualizes how value is created in public services. The study identifies current shortcomings in the field and offers a series of directions for future research where service management theory can contribute greatly. Research limitations/implications - The review encourages service management research to examine the dynamic, diverse and complex nature of public services and to recognize the importance of this context. The review calls for an interdisciplinary public service management community to develop, and to assist public managers in leveraging service logic.

Originality/value - The review positions service research in the public sector, makes explicit the role of complex networks in value creation, argues for wider engagement with public service management, and offers future research directions to advance public service management research.

Keywords Public service-dominant logic, Service-logic, SDL, Goods-logic, GDL, Value, Co-production, Co-creation, Governance, Public sector, Research agenda.

Paper type General review 


\section{Introduction}

The service management literature has largely neglected the public service context. This is surprising given its importance and impact on the everyday lives of citizens, for instance, public expenditure on health services is almost three times that of private citizens, private companies and not-for-profit organizations (OECD, 2017); with similar contrasts found in the areas of education and welfare. Moreover, managing public service delivery is very different to the management of services in the private sector. Public services are typically more complex, encompass a broader array of service providers and stakeholders, and require higher levels of transparency and accountability (Osborne et al., 2013). The purpose of this paper, therefore, is to advance understanding of service characteristics within the public setting, and to highlight the need for special theoretical treatment of this important context.

On the surface, public services are different from private sector services because they are provided by the state (or government). Thus, public services tend to reflect the political and institutional behaviour of these organizations (Lane, 2000). This conceptualization is, however, very simplistic and fails to recognize the dynamic and interconnected nature of modern public services. Contemporary public services are embedded within a network comprised of multiple actors whose direct and indirect interactions do not exist in isolation but as part of a wider ecosystem (Jaakkola et al., 2015). This characterization of public services as a network (or ecosystem) is consistent with the broader service management literature, where the network or ecosystem view of services has emerged as the dominant view within the research on service-dominant logic (SDL) (e.g., Jaakkola and Hakanen, 2013; Jaakkola et al., 2015). Compared to the private sector, however, public service networks are more complex as they comprise "multiple and/or conflictual users" (Osborne et al., 2013, p. 150), with a greater propensity for outsourcing and contracting out of service elements (c.f. Tax et al., 2013). Moreover, with increased marketization and mixed service delivery models involving public, private and third sectors (Hodgkinson and Hughes, 2014), it is clear that contextual differences exist not only between public and private sector services (Van de Walle, 2016), but also among and within public sector organizations (Hodgkinson and Hughes, 2014). If we accept that the purpose of theory is to understand and explain the world around us, then we must also acknowledge that the failure of existing service management theory to take into consideration context-specific insights has contributed to weak mid-range theories with ambiguously defined boundaries, limited practical value, and poor predictive validity (Van de Walle, 2016). 
While it may be argued that service differences between the public and private sectors have diminished in recent years, as governments have sought to find savings through greater use of market mechanisms and the adoption of corporatization, it is contended that these efforts have not materially changed the political and institutional differences. The most extreme example is visible through the recent adoption of austerity measures. The aggressive pursuit of efficiency and productivity gains has acted to highlight a key difference between the private and public sectors by creating a platform for disenfranchised citizens to gather and voice their opposition to the reduction and/or removal of important public services. These pressures have been particularly prevalent in the advanced economies of the UK, US, Australia, New Zealand and parts of Europe, where governments are now under increasing pressure to maintain high standards of living and deliver better public services despite reduced economic means (Osborne et al., 2013). This illustrates, among other things, how contextual differences remain between the private and public sectors, and how these differences are adding to higher levels of volatility within public sector networks.

This review contributes to the broader service management literature by highlighting how public service networks differ from private service networks. This responds directly to a call for research to help us better understand how value is created in different service settings and within systemic and fragmented service contexts (Verleye et al., 2017). The aim of the review is to present context-specific insights regarding the development and delivery of public services, offer an interpretation of the shift from goods-dominant to service-dominant thinking within the public sector, and inform service management theory by identifying future directions for research in the area of public services. This is achieved by applying SDL as a lens for understanding value creation in the public sector, which to date, has largely been characterized by a goods-dominant logic (GDL) where services are produced by organizations in relative isolation from their customers (Åkesson and Skålén, 2011). The review also adds to recent research which has highlighted the need for public sector organizations to embrace a service culture (Enquist et al., 2011); one which is able to meet divergent stakeholder interests across complex public service networks. Thus, as Osborne et al. (2013, p. 151) highlight, "what is now needed is an agenda of empirical research to test out the insights and limitations of this theoretical approach [in the public sector]."

To achieve this, the paper seeks to build a bridge between service management theory and theory in the field of public management, which until now have largely developed exclusively of one another. Service management theory has the potential to transform public services, but has typically been neglected in public management research despite its potential 
to offer new ways forward for public service management (Osborne et al., 2013). This review serves as a means to unite public management and service management literatures and direct future public service management research, paving the way for transdisciplinary research as called for by Gustafsson et al. (2016).

\section{Approach}

Drawing on the work of Ravishankar et al. (2011), the paper adopts the approach of soft positivism $^{1}$. This allows the analysis to be conducted with certain expectations based on prior theory, while also allowing for unexpected themes and explanations to emerge, as is more typical of interpretivist approaches. First, existing research on public services is examined to trace the progress of public service management and the corresponding developments in how public services have been addressed. This aspect of the analysis implies a positivist approach in deciding, in advance, expected factors. Second, in contrast the softer stance gives the freedom to develop themes and theoretical categories without having to force data into existing themes. The interpretivist dimension is used specifically to capture emerging themes, identify current shortcomings in the field, and set directions for future research.

To enable an analysis at different levels of a complex service network there is a need to account for the service system at the organizational level and the system of systems at the value network level (Pinho et al., 2014). The positivist stance gives this study the necessary initial focus drawn from existing knowledge on the two distinct levels to public value creation (Hartley et al., 2017) conceptualized in the Public Service Network Framework (PSNF), shown in Figure 1. Here value creation is not located in the customer's sphere as is typical of SDL application (Grönroos, 2008), rather value is split across two levels: at the 'domain' level, public value is conceptualized as that which is created or added (i.e., a public bottom-line) through the activities of public service organizations (hereafter PSOs) (e.g., hospitals, transport, schools, etc.), service managers (e.g., legislators, elected and appointed executives, etc.), and is influenced by service policy (e.g., healthcare, social care, etc.); while at the 'sphere' level, public value is positioned as the public interest which is shaped by political system (e.g., democracy), citizenship (e.g., mutuality, collective good, and selfrestraint), and governance (e.g., global and local arrangements, formal and informal norms and understanding). Cleary the composition of complex networks will vary, but the PSNF is

\footnotetext{
${ }^{1}$ Soft positivism has its origins in law and refers to morality figuring in the determination of the existence of valid law (Mitrophanous, 1997). Translated into management scholarship, soft positivism refers to allowing new insight and knowledge to emerge beyond pre-established frameworks, constructs, and knowledge.
} 
generic in design so that it is applicable across service networks and importantly is explicit about the interactive and networked nature of value creation (domain-level and sphere-level), which has typically only been addressed implicitly in SDL (Vargo and Lusch, 2008). This supports the call from Enquist et al. (2011, p. 235) who contend that “... in a value network, a more dynamic approach is required to define, design and deliver the service solutions than is required in a value chain" for public services.

Please insert Figure 1 here

Though public management research has typically been devoid of service management theory integration, three prominent public management scholars who have pushed for greater service management thinking in the field of public management were invited to submit short reflective commentaries. These scholars were specifically targeted given their international research profiles, contribution to the field of public management, and by virtue of their influence in advancing the public service management research agenda; these scholars are:

- Tony Bovaird, Emeritus Professor of Public Management and Policy, University of Birmingham, UK.

- John Bryson, McKnight Presidential Professor of Planning and Public Affairs, University of Minnesota, US.

- Zoe Radnor, Professor of Service Operations Management and Dean of the School of Management, University of Leicester, UK.

Each of these scholars was asked to frame their commentary around three core research questions (full commentaries are included in Appendix A):

$R Q 1$. How has the concept of 'service' affected your own research in the field of public management?

RQ2. How has public service management research developed in recent years?

$R Q 3$. To push the field of public service research forward, what do you perceive as the critical issues to be addressed?

The research questions are intentionally open-ended based on the areas of interest of the review (e.g., past, present, and future directions), and were formulated to direct the flow of narrative while providing a flexible setting for the commentators to explore a wide-range of related issues in public service management; reflective of the interpretivist side of the 
approach adopted. The commentaries were analysed by travelling back and forth between the narratives and emerging structure of theoretical arguments from across public management and service management fields. The use of expert commentaries helps to ensure content and face validity of the review's findings, and as a methodological approach has been used effectively in service management literature to set appropriate research agendas, which is the aim here (e.g., Fisk et al., 2016; Jaakkola et al., 2015). Consistent with Jaakkola et al. (2015), then, the commentaries are used to broaden the study's perspectives, assist in identifying matters of relevance to public service management, and identify emergent issues related to service phenomena in the public sector, with excerpts used to augment the review.

The paper is structured as follows: first, a literature review establishes the predominance of GDL at the expense of SDL in the public sector. The conceptual background of goods-dominant thinking in the sector is then examined to address RQ1. In response to RQ2, the recent application of SDL to public service contexts is considered and its merits discussed in light of complex service networks. Following this, the emergent theme of performance measurement as both a barrier and driver of service logic is presented, prior to a discussion that outlines shortcomings of the field and future research directions; in line with RQ3. To close, conclusions are drawn and implications for public service management theory and practice are discussed in light of the limitations of the review.

\section{From GDL to SDL? The public sector journey}

Traditionally, the public sector is recognized as a provider of public goods, informed by management theory that has been derived from research conducted in manufacturing rather than the services sector (Osborne et al., 2013). Under GDL, value is embedded in an organization's offering of products ( ̊kesson and Skålén, 2011) and this has dominated public service management thinking. This has been evidenced in the performance measurement of public services, reducing the potential for customer-oriented delivery (Enquist et al., 2011). Public transport, for instance, has typically been understood as a "public good" evoking an internal cost orientation at the expense of a market orientation (Gebauer et al., 2010).

The expansive use of outsourcing of public service provision to private agents is a case in point. Service externalization is a mechanism which is attractive to the political principal since the economic and/or political costs of developing services internally is typically much higher relative to the costs of outsourcing to private agents. Public-private partnerships are an illustration involving a variety of structures where risk and responsibility 
is shared between public and private actors. Private finance initiatives are another form of such partnership working in the public sector, but are only possible with funding credits agreed and provided through government and may be more accurately described as a type of contracting or procurement. Moreover, there has been increasing externalization of services across not only the public and private sectors, but also the public and third sectors with private companies providing domiciliary care, voluntary bodies proving community based drug and alcohol services, and arms-length management organizations providing housing services; the providers of public services are therefore markedly different in their sectororigins (Bovaird et al., 2012). A key driver of such partnership or cross-sector working has been the pursuit of efficiency and effectiveness, though "the relationship between contractual governance and performance measurement has traditionally been studied from the perspective of conventional production, driven by 'goods-dominant logic'”' (Enquist et al., 2011). This is the opposite of SDL that is conceptualized as customer-oriented and relational (Vargo and Lusch, 2004, 2008); yet failure to focus on the actual process of service deliverywhere service production and consumption occur contemporaneously-as espoused under SDL (e.g., Vargo and Lusch, 2004, 2008) is endemic to public services management (Osborne et al., 2013).

This neglect arguably may be driven by pragmatic research implications, such that to capture the service delivery process is in itself uniquely challenging in the public sector context (Verleye et al., 2017). Take the UK National Health Service as an example, there are a range of actors within this complex service network that span across the organizationallevel and network level from hospital management (e.g., board, governors, managers), hospital operators (e.g., clinicians, nursing staff, administrators), commissioning agencies (e.g., support units, regional offices, clinical groups, area teams) regulators (e.g., NICE, Healthwatch, MONITOR, Care Quality Commission, etc.), local actors (e.g., patients, carers, public, general practitioners, local government, health and wellbeing boards, oversight and scrutiny committee, education and training boards, etc.), and governmental bodies (e.g., Department of Health, NHS England, etc.), each of whom can be considered essential resource integrators to service value creation (Vargo and Lusch, 2008), but each with conflicting and diverging needs and wants from the delivery system (Verleye et al., 2017); illustrating the sheer complexity of the public service value network.

This complexity may explain why in practice GDL has persisted, as it may be easier for practitioners to understand services as discrete and transactional rather than processual and systemic. However, public services must be understood as services "with the distinctive 
service dominant logic and managerial challenges that this implies, and must hence reject the fatal flaw contained within current, product-dominant public management theory" (Osborne et al., 2013, p. 136). This move toward SDL is now explored by drawing on literature from the public management and service management fields, and excerpts from the commentaries.

\section{A public goods-logic}

This section addresses how public services have been characterized over time by tracing the development of public service management research as examined in the public management field; addressing RQ1.

\section{From Public Administration to New Public Management}

The traditional view of public service management, known as Public Administration (PA), focused on the 'rule of law' and the administration of rules and guidelines with services provided for all citizens 'from the cradle to the grave' (Hood, 1991; Osborne, 2010). The central tenets of administration and bureaucracy within PA ensured a split between public service managers administering public policy and politicians using bureaucracy to implement policy changes (Hood, 1991; Fryer et al., 2009; Osborne, 2010). Other key elements of PA included a dedication to incremental budgeting within PSOs, and the dominance of the public service manager as 'the professional' delivering public services. However, as Professor John Bryson notes in his commentary, in traditional PA managers have limited discretion, they are not directly involved in the democratic process, and accountability is hierarchical. As a field of academic study, PA provides an important mechanism to understand public management and performance in a historical context and where services are delivered along more 'traditional' goods-dominant notions of public management (Osborne, 2010). However, the prominence of PA in developed western economies diminished from the late 1970s onwards when the needs of service users began to outstrip the resources available to PSOs. This forced a move towards the private sector for new ways to provide improved services to service users and citizens with limited resources (Fryer et al., 2009; Hood, 1991).

This adoption of private sector management techniques is referred to as New Public Management (hereafter NPM). The key components of NPM include the development of 'hands-on' professional management in PSOs (Hood, 1991) and the use of clear and specific measures of performance with a greater focus on output controls, budgetary discipline, and frugality with public resources (Hood, 1991; Fryer et al., 2013). This shift from traditional PA toward the benefits of market competition in public service delivery resulted in greater 
decentralization and marketization of public services (Hood, 1991; Fryer et al., 2013). Emeritus Professor Tony Bovaird highlights this move to working with the private sector:

Research into partnership and collaborative working took off in business schools in the 1980s but it was only the 1990s that these topics became a major theme in public management, largely at the same time as they became a key issue with governments around the world, e.g. in the form of public-private partnerships (PPPs).

The drive for NPM in the UK, USA, Europe, Australia and New Zealand, led PSOs to adopt a plethora of private sector style performance measures, performance indicators and performance management techniques (Johnston et al., 2002), including the 'Balanced Scorecard, the Performance Prizm, and Lean Thinking, Six Sigma, Business Process Reengineering, Kaizen and Total Quality Management, as well as blended approaches such as Lean Six Sigma' (Professor Zoe Radnor). Many of these private sector management practices have helped to deliver improvements to public services (Hood, 1991; Radnor and Noke, 2013), and though NPM has been characterized by the increase in regulation and inspection of PSOs, it has delivered professionalization of management roles in the sector and, arguably, increased standards of management (Osborne, 2010; Radnor and Noke, 2013). By the late 1990s, however, many authors had begun to criticize the assumption within NPM that private sector management practices could be readily and successfully applied in PSOs, with reports that their application had caused problems such as prioritizing efficiency over the long-term sustainability of public value (Fryer et al., 2009; Osborne, 2010; Radnor and Noke, 2013). Professor John Bryson explains the rise (and fall) of NPM in his commentary:

\footnotetext{
NPM arose out of a concern with government failures, a belief in the efficacy and efficiency of markets, a belief in economic rationality, and a push away from large, centralized government agencies toward devolution and privatization. In terms of values, NPM has focused clearly on service efficiency and effectiveness, often to the detriment of other important public values. For example, there is clear evidence that NPM-style public welfare policies can undermine citizenship behavior in recipients (e.g., Soss, et al., 2011), in contrast to prior public services approaches that actually increased citizenship behavior (Mettler, 2007).
}

There has been a growing move away from the rhetoric of NPM, as countries such as the UK, USA, New Zealand, and Scandinavia face greater austerity in public spending, towards governments promoting wider network management under a broader framework 
termed New Public Governance (Osborne, 2010; Osborne et al., 2013). Osborne et al. (2015, p. 425) emphasize, "PSOs are now part of complex public service delivery systems where their mission-critical objectives require the successful negotiation of relationships within these systems - with policy makers, other PSOs, service users, citizens, and indeed a range of service system elements and stakeholders"; as observed by Professor John Bryson:

\footnotetext{
While the challenges that prompted NPM have not disappeared, new material conditions and challenges have emerged. They center on how to govern, not just manage, in increasingly diverse and complex societies facing increasingly complex problems (Osborne, 2010; Pollitt and Bouckaert, 2011)...Scholars arguing for the new approach see public value emerging from broadly inclusive dialogue and deliberation. This work can engage many different kinds of people, including public-spirited managers from across sectors and citizens. Citizens thus move beyond their roles as voters, clients, constituents, customers, or poll responders to becoming problemsolvers, co-creators, and governors actively engaged in producing what is valued by the public and good for the public (De Souza Briggs, 2008).
}

Yet, as Osborne et al. (2013, p. 138) note, "what is remarkable is that the [...] debate about the management of public services has been conducted in almost ignorance of [service management theory], and despite its apparent relevance".

\section{A public service-logic}

This section addresses the recent developments in public service management, uniting both the public management and service management fields. In doing so, this section examines how public service management has transformed in recent times; in response to RQ2.

Proceeding from NPM, discourses in the field of service management and specifically SDL have been applied within the public sector focusing on the distinct nature of the service experience for customers and service users (Osborne et al., 2013). In the service management literature, SDL views all actors of the service value network as resource integrators who interact to gain resources for use in their respective value creation processes (Vargo and Lusch, 2008). Within this, customers and service users are co-creators and co-producers of the services they consume (Verleye et al., 2017) with the production and consumption of services occurring simultaneously (Osborne et al., 2013). This represents an important shift in perspective in the public sector from GDL to SDL ( kesson and Skålén, 2011). As Professor Zoe Radnor emphasizes in her commentary: 
[...] the majority of 'public goods' (whether provided by government, the non-profit and third sector or the private sector) are in fact not 'public products' but rather 'public services' that are integrated into people's lives. Social work, health care, education, economic and business support services, community development and regeneration, for example, are all services provided by service organisations rather than concrete products, in that they are intangible, process driven and based upon a promise of what is to be delivered. Public services can of course include concrete elements (health care or communications technology, for example). But these are not 'public goods' in their own right - rather they are required to support and enable the delivery of intangible and process driven public services.

While SDL has been explored in the context of single public service settings such as transport (Enquist et al., 2011; Gebauer et al., 2010), health (Verleye et al., 2017), and employment (Åkesson and Skålén, 2011), according to Pareigis et al. (2012) there remains a lack of knowledge of how customers actively participate in servicescapes-combination of service and landscape-which forms the service experience that is central to SDL. However, although Pareigis et al. (2012) among others situate their study in a public service (transport) they overlook the contextual peculiarities of the public sector, where distinctions can be drawn between customers, consumers, service users, and citizens, and the characteristics of the public sector landscape differ to that of the private sector. Concurrently, Osborne et al. (2013) have extended the principles of SDL to the public sector at large by proposing a Public Service-Dominant Logic (hereafter PSDL) that refocuses public service management around the co-creation and co-production of public services with service users and citizens, but within the characteristics of the public sector landscape. This shift in focus is discussed by Emeritus Professor Tony Bovaird:

[...] At first, this co-production was often identified with the contributions which service users make at the 'moment of truth', where both service user and producer have to play a role for the service to work. However, over time it also became clear that the preparation made by service users, often long before the 'moment of truth', may also be a key contribution to the eventual effectiveness of public services...So, 'public services' are everybody's business - produced by multiple stakeholders, including their users, for the benefit of multiple stakeholders, including (but not exclusively) their users.

Osborne et al. (2013) outline four propositions of PSDL: First, by focusing on a public service-dominant approach, service users and citizens are "situated as essential stakeholders of the public policy and public service delivery processes and their engagement 
in these processes adds value to both" (p.149); Second, the strategy of PSOs is a 'service promise' or offering, which is shaped by service users and staff delivering the service. This service promise provides PSOs with a robust framework to develop better trust and relationships with other PSOs, service users and citizens; Third, co-production becomes an "inalienable component of public service delivery that places the experiences and knowledge of the service user at the heart of effective public service design and delivery" (p.149); Fourth, there is a need for PSOs to use operations management and a public service-dominant approach to produce more efficient and effective public services; Professor Zoe Radnor elaborates:

Service operations management is concerned with both the output or outcome of 'the service' in the sense of 'customer service' and also the service organisation itself - in the way it configures, manages and integrates its (hopefully value-adding) activities (Johnston and Clark, 2008).

As a new theory for public service management, PSDL puts service users and citizens at the heart of public service delivery e.g., through the co-creation and co-production of its services. Refocusing the role of the citizen and/or service user is therefore central to PSDL; for example, in their examination of service blueprinting in a university, Radnor et al (2014) found that service user value was created by allowing students to co-create the redesign of the service. Similarly, in her examination of co-production of outcome based contracting in public services, Farr (2016) reports that public value is created when PSOs are able to understand the differing experiences of service users. Åkesson and Skålén (2011) also note that within a public employment service, employees adopted a new customer-oriented approach by viewing customers as collaborative partners. Hence, understanding the role of service users in the delivery system can help PSOs to find new ways of understanding and measuring public value. Though proving valuable to the study of PSOs, PSDL remains in its infancy and both Emeritus Professor Tony Bovaird and Professor John Bryson point to key themes for development within and alongside this approach:

[There is] need for clearer and better-tested logic chains connecting what we do to the outcomes we want suggests a further requirement in public services research - to reinvigorate an understanding of the dimensions of service quality (Emeritus Professor Tony Bovaird). 
$[\ldots]$ more work is needed on developing and testing the usefulness of approaches to mapping the public value creation (or destruction) process and its effects on service provision and service recipients (Professor John Bryson).

\section{PSDL and performance: An emerging dimension}

In examining the predominance of GDL in public service delivery, it is apparent that there are core performance implications to be considered in the move towards PSDL. Through the interpretivist side of the soft positivist approach adopted, the theme of performance measurement emerged from the expert commentaries and is explored.

Traditionally, public service efficiency has centred on reducing public services costs without considering the sustainable delivery of services to service users, in keeping with the predominance of GDL (Osborne et al., 2013; Radnor and Noke, 2013). As a result, existing models of public performance measurement do not directly address public value or how different groups of service users are accounted for in public service performance. This is a measurement limitation highlighted by Emeritus Professor Tony Bovaird:

\footnotetext{
$[\ldots]$ how can we assess more convincingly the potential value of pathways to outcomes which include co-production? This involves assessing changes to the range of outcomes brought about by the co-production initiative and also, of course, the changes to the costs to different stakeholders. Most importantly, it involves measuring the costs to co-producers, especially citizens, when they move to a more intensive co-production model. The costs experienced by citizens who co-produce have so far received almost no attention in the literature, although a general equilibrium welfare economics approach would suggest that even voluntarily accepted costs may have disadvantageous effects on citizens (e.g., if they underestimate the likely longterm commitments which they are taking on) - and the net benefits to co-producing citizens may be even lower if their co-production decision is not entirely voluntary.
}

Andersen et al. (2016) have attempted to 'map' the wider aspects of performance in their systematic review of the public service performance literature. In their 'conceptual space of performance' framework the authors seek to capture the intangible nature of public services by considering six aspects of performance measurement: stakeholders, formality, subjectivity, type of process focus, type of product focus, and units of analysis. For each, they propose a question which should be used to measure the quality, validity and effectiveness of a public service performance measure (e.g., 'who decides what good performance is?), which highlights key features of the public sector landscape that will differ to the private sector 
landscape and should be accounted for in the application of SDL. This highlights the range of outcomes and the associated problem of trade-offs in measuring public service performance:

In previous work, I have proposed the 'governance impossibility' theorem, whereby it is not possible for all the principles of public governance to be realised simultaneously. All the more likely, then, is the need for explicit trade-offs between quality of service, quality of outcomes and the achievement of governance principles, all of which dimensions need to be convincingly evaluated. This will be a key challenge for future public services management research (Emeritus Professor Tony Bovaird).

It becomes clear, then, that the relationship between performance measurement and service improvement in the sector is not clearly defined. Johnston et al (2002), for instance, report that performance measurement frameworks such as the Balanced Scorecard have actually served to overload public managers with too many performance measures. Attempting to standardize performance measurement across the sector is problematic given the variety of performance objectives that exist. Micheli and Neely (2010) for example contend that there is little consistency in the definitions and use of performance indicators across PSOs. This also leads to the question: why are performance measures used in the first place? As Moxham (2013) uncovers, rather than a means to steer service improvement in the public sector, performance measures have often been used to ensure regulatory compliance; subsequently, little effort is made by PSOs to interpret performance data which in turn hinders real performance improvements (Moxham, 2013). Taken collectively, the conceptualization and measurement of public service performance is in clear need of attention, in line with PSDL. As appropriately highlighted by Enquist et al. (2011, p. 236), then, new performance indicators based in SDL "will become increasingly important if public service businesses are to move towards a true service culture".

\section{Future research on public service management}

This section directly addresses RQ3: To push the field of public service research forward, what are the critical issues to be addressed? There is an important distinction to be made in how 'service' is viewed in the public sector, which concerns whether the foci is indirect or direct benefits to citizens, both individually and collectively. This distinction is important since the application and implication of service logic-the provision of value-supporting processes (Grönroos, 2008)-may be contingent on the perspective taken. For example, would 
an imprisoned citizen view their service experience in the same way as that of a citizen using public transport? It is very unlikely. Adopting the latter view affords greater conceptual clarity by establishing appropriate parameters to investigate service management in the sector. This presents a clear opportunity for theory development. For instance, Professor Zoe Radnor emphasizes the lack of engagement with the service concept in the public sector:

[...] public sector organisations should recognise that they are a service organisation so should engage with service operations management theory and frameworks [...] I have noted that operations management methodologies are 'context specific' and this means that the discipline needs to adapt $[\ldots]$.

Specifically, from an outcome-orientation, how actors can, do, or should contribute to the creation of value emphasizes the under-examined role of value processes i.e., pathways to value creation. Theory generalization across service-contexts has resulted in the neglect of insights for PSOs contributing to a lack of comprehension regarding the 'service' concept in the public sector. This illustrates the importance of applying and adapting service management theory to the public sector context, highlighting a growing emphasis on public value creation and what this might actually mean for public service management. The broader PSDL approach in turn emphasizes the usefulness of drawing on other disciplines outside of the traditional public management field. Yet, there has been limited inclusion of other disciplines in the study of public service management (e.g., Osborne et al., 2013), as Professor John Bryson explains in his commentary:

There has been a steadily increasing volume of research on public service management over the course of my career. There are now many more journals and professional organizations attending to public service management. Unfortunately, too much of this research is uninformed by what is going on in other disciplines, including mainline business management, political science, and law (Wright, 2011). There has been less attention to public services management, although that is changing (e.g., Andrews et al., 2011; Hodgkinson and Hughes, 2014; and Osborne, et al., 2015).

The increasing application of service logic illustrates the value of applying service management theory to the public management field (that has been narrowly concerned with policy and goods-logic) to better understand and inform public service management i.e., to set the agenda. Though significant steps have, and are, being taken to explain different value 
processes from different theoretical foundations, this effort is still building momentum and remains under-examined.

Public value emerges from the interaction of actors, such as the contribution made by citizens (as problem-solvers, co-creators, and governors) to public services, which is in contrast to the NPM rhetoric that saw competition and private sector acumen as a solution to the ills of the public sector. The application of PSDL is one approach to more effectively capture value creation processes. Professor John Bryson elaborates more on this shift from PA and NPM and what it means for public managers:

Public managers' role thus goes well beyond that in traditional public administration or NPM; they are presumed able to help create and guide networks of deliberation and delivery and help maintain and enhance the overall capacity of the system...In both traditional public administration and NPM managers are not directly involved in the democratic process, viewed mainly as elections and legislative deliberation. In contrast, in the emerging approach government delivers dialogue and catalyzes and responds to active citizenship in pursuit of what the public values and what is good for the public.

While understanding of public service management has progressed considerably in recent years, the review depicts a level of complexity within the public service management domain where a value network perspective is becoming increasingly necessary to accurately reflect and capture a changing environment, but as yet has been rarely investigated. Three notable exceptions are found in the service management literature: in their application of SDL, Verleye et al. (2017) examine the causes of value destruction across a public health network, Enquist et al. (2011) examine the relationship between contractual governance and performance measurement in a value network for public transport, while Pareigis et al. (2012) explore constellations of activities and interactions to understand the customer service experience in public transport; illustrating the value of applying service management theory for a public service network perspective. Moreover, the review depicts a fuller picture of network actors roles than has been previously captured, both in terms of expectations to instil SDL (Åkesson and Skålén, 2011), but also how their actions are constrained by wider norms and beliefs through competing institutional logics in complex service networks (Verleye et al., 2017). Nevertheless, a network perspective in public service management research will help to capture public value creation at both domain and sphere levels of the PSNF: 
[Research investigation must be] integrated with a broader paradigm that emphasises both the governance of inter-organizational (and cross-sectorial) relationships and the efficacy of public service delivery systems rather than discrete public service organizations (Professor Zoe Radnor).

The review emphasizes an emerging need to go beyond traditional measures of efficiency and effectiveness with the aim to more accurately capture service effectiveness and to develop a true service culture (Enquist et al., 2011), as supported under PSDL. This broadening of service evaluation will help to establish if different expectations, goals, and pressures can be reconciled across and between the domain and sphere levels of public value creation, which in turn will provide a basis to measure the contribution of PSDL to public service management. Hence, the need to broaden the application of service logic and service management theory beyond the 'customer' sphere, as Professor John Bryson asserts:

[...] public services research in a democracy should also attend to the effects of those services on democracy itself in terms of intellectual, human, social and political capital; citizenship; and accountability. What services help their formulators, implementers, recipients, and democracy itself become stronger, and in what ways, and which do not? Which help promote democracy, and in what ways, and which do not?

\section{Shortcomings and future research directions}

The PSNF is embedded in priory theory and can serve as a guide to position future public service management research for theory development. To complement this, the interpretivist dimension of the review signals a number of shortcomings in the field of public service management as summarized in Table I. The intention here is not to provide an exhaustive list but to offer a focus on core areas where the field of service management can contribute greatly. A number of potential directions for future research that emerge from the analysis are highlighted in response to four key shortcomings of existing knowledge.

Please insert Table I here

Taken collectively, the review contributes to theory on value creation in public services and calls for more inter-disciplinary research between public management and service management scholars to explore the application and adaption of service logic to public services, as Professor Zoe Radnor appropriately surmises in her commentary: 
[It is] service management theory, it is argued here, that should inform our theoretical and conceptual understanding and analysis of the management and delivery of public services (Osborne et al., 2015).

\section{Conclusions}

\section{Theoretical contributions}

This review develops the concept of 'service' in public service management, with the aim to advance current understanding of this important context for service management research. To this end, the review provides the impetus for new research into public service management and three conclusions emerge.

First, the paper shows how the concept of service has been progressed in public management research and illustrates the often ambiguous use of the concept to capture all public sector interventions. This concurs with Fountain (2001) who suggests that a better understanding of service to citizens, as opposed to services for citizens, is the key to unlocking greater levels of public value. Not surprisingly, the review highlights that a richer understanding of service is more common within public services providing direct benefits to individual citizens and the citizenry. However, $\mathrm{Ng}$ et al. 's (2009) examination of defence contracting shows that this distinction is also valid in other public settings, where a better recognition of 'service' was essential to the co-creation of value.

This lack of appreciation of the subtleties of service logic has driven simplistic notions about public services that are often uninformed by the work in other disciplines (Osborne et al., 2013). The review of public services presented here reveals a more complex set of activities between a diverse set of network actors that has the creation of public value as central to its thinking. The wider engagement of service management scholars to explore this complexity and extend the relevance of service logic to address the creation of public value in more depth is necessary. This observation is consistent with the work of Moore (1995) who argued that a failure of the public management field to engage with other disciplines had inhibited understanding and progress toward the creation of public value. The PSNF makes a very useful contribution in this regard, and will help to appropriately position studies of services in the public sector landscape, and importantly, to distinguish between the domain and sphere levels of value creation in public services.

Second, a clear divergence emerged between the dominant approaches of PA and NPM, and a new emerging perspective to public service management research that offers to more appropriately capture new material conditions and challenges that characterize 
increasingly diverse and complex societies. Consistent with the work of Alves (2012), the review highlights that the emphasis has shifted to include the value network and the complexity of interactions therein, as well as a substantial widening of what outcomes should be included to better understand value processes. This has helped to establish the broader approaches that underpin public value creation, and has offered a more fitting understanding of the role of network actors within the full process of public services delivery.

However, criticism has begun to emerge regarding the efficacy of some of the approaches used to engage stakeholders in the service improvement process. For instance, Radnor and Osborne (2013) suggest that lean, workshop-driven approaches have failed to impact on public sector culture and structures, and that a lack of understanding of the underlying value creation processes of citizens has undermined the benefits derived from such approaches. To this end, Lusch and Nambisan (2015) argue that service innovation efforts need to be supported by stronger theorization, more empirical evidence, and provide greater guidance for practice to ensure a better understanding of how service logic holds across different application settings. The review also highlights that the current literature on public service improvement is too biased to specific service settings, western-centric theory, and empirical evidence derived from developed economies. To this end, a more theoretical approach to collaborative value creation informed by PSDL should go a long way to resolving these concerns.

Third, in tracing the progress in public service management from PA and NPM to the newer emerging perspective of PSDL, the past and present of public service management can be more clearly understood by scholars in the service management field; this is important given that the roots of public service management will inevitably influence its future growth. It is the future directions of the field shown in Table I, however, where service management theory can contribute substantially, since a service-dominant approach has the potential to both transform "our understanding of public management tasks and offers new ways forward for their resolution" (Osborne et al., 2013, p. 136). Already there is alignment between the themes of, and conversations in, PSDL and the service management field and it is hoped that an interdisciplinary public service management community will develop; one that embraces diversity of thinking to advance understanding of service phenomena in the public sector (e.g., Gustafsson et al., 2016), as after all, public services are just that - services.

\section{Implications for practice}


With increasing fiscal demands across public services of western economies there is a need for practitioners to focus on the actual delivery of services rather than treating these as discrete and transactional. By viewing all actors as resource integrators there is a clear opportunity for both enhanced effectiveness and efficiency, but this will rely on all actors being driven by service logic within the complex public value network. This is a big challenge for network actors who have typically succumbed to cost-oriented action (Gebauer et al., 2010) for short-term gain (and survival) when facing economic pressures. Such actions have been observed to drive value destruction in complex service networks (Verleye et al., 2017) and this in part has been a consequence of narrow public service evaluation, which continues to reflect GDL.

Arguably, public value creation is far more complex that notions of 'customer value' espoused in SDL given the multiple stakeholders, conflicting needs and far reaching outcomes of public services (Osborne et al., 2013). Yet, if a true service culture is to develop there is a need to develop inter-organizational performance indicators (Enquist et al., 2011) that address key questions across the domain level such as 'Why has it been so hard to achieve cost-effective collaboration in public services, which appears to have become commonplace in the private sector?', and also across the sphere level such as 'To what extent can government deliver dialogue, and catalyze and respond to active citizenship in pursuit of what the public values and what is good for the public?'. This broadening of service evaluation is a necessity if the value of PSDL to practice is to be understood and championed by public network actors. Essential to this will be the use of feedback loops to appropriately capture the cyclic nature of public value creation for sustained service delivery. However, this poses further challenges for public services that have traditionally payed lip service to the extensive inspection and performance measurement enforced under NPM, which have had the opposite effect of their intension i.e., service deterioration rather than service improvement (Moxham, 2013).

This review acknowledges that the majority of public service management knowledge, and within that PSDL, has been derived from western-centric theorization and empirical evidence; but, as the antithesis to PSDL is GDL always bad? In the context of public services in developing economies, GDL might be a more appropriate approach for practitioners. For instance, a goods-dominant perspective might be more effective for delivering greater access to basic public services such as clean water, relative to the customer-oriented and relational service logic. Thus, the distinctiveness of different public 
services and service contexts needs to be remembered (Osborne et al., 2013); this is where the PSNF can help interpret the different characteristics of complex public service networks.

\section{Limitations}

This review was not intended to be an exhaustive overview of the work that has, and is, being undertaken by public management and service management scholars. Similarly, had the review included a larger number of commentators, or indeed different commentators, there might have been variation in the shortcomings and future research directions presented. Nevertheless, the general themes uncovered are perpetual to the field and, therefore, this review can serve to guide future public service management research.

\section{References}

Åkesson, M. and Skålén, P. (2011), "Towards a service-dominant professional identity: An organisational socialisation perspective", Journal of Service Management, Vol. 22 No. 1, pp. 23-38.

Alves, H. (2013), "Co-creation and innovation in public services", The Service Industries Journal, Vol. 33 No. 7-8, pp. 671-682.

Andersen, L.B., Boesen, A. and Pedersen, L.H. (2016), "Performance in public organizations: Clarifying the conceptual space", Public Administration Review, Vol. 76 No. 6, pp. $852-862$.

Andrews, R., Boyne, G.A., Law, J. and Walker, R.M. (2011), Strategic Management and Public Service Performance, Palgrave Macmillan, New York.

Bovaird, T., Dickinson, H. and Allen, K. (2012), Commissioning Across Government: Review of Evidence. Third Sector Research Centre Research Report (86). University of Birmingham, Birmingham.

De Souza Briggs, X. (2008), Democracy as Problem Solving: Civic Capacity in Communities across the Globe, MIT Press, Cambridge, MA.

Enquist, B., Camén, C. and Johnson, M. (2011), “Contractual governance for public service value networks", Journal of Service Management, Vol. 22 No. 2, pp. 217-240.

Farr, M. (2016), "Co-Production and value co-creation in outcome-based contracting in public services", Public Management Review, Vol. 18 No. 5, pp. 654-672.

Fisk, R.P.P., Anderson, L., Bowen, D.E., Gruber, T., Ostrom, A., Patrício, L., Reynoso, J. and Sebastiani, R. (2016), "Billions of impoverished people deserve to be better served: A call to action for the service research community", Journal of Service Management, Vol. 27 No. 1, pp.43-55. 
Fountain, J. E. (2001), "Paradoxes of public sector customer service", Governance, Vol. 14 No. 1, pp. 55-73.

Fryer, K., Antony, J. and Ogden, S. (2009), "Performance management in the public sector", International Journal of Public Sector Management, Vol. 22 No. 6, pp. 478-498.

Gebauer, H., Johnson, M. and Enquist, B. (2010), "Value co-creation as a determinant of success in public transport services: A study of the Swiss Federal Railway operator (SBB)", Managing Service Quality: An International Journal, Vol. 20 No. 6, pp. 511530.

Grönroos, C. (2008), “Service logic revisited: Who creates value and who co-creates”, European Business Review, Vol. 20 No. 4, pp. 298-314.

Gustafsson, A., Högström, C., Radnor, Z., Friman, M., Heinonen, K., Jaakkola, E. and Mele, C. (2016), "Developing service research-paving the way to transdisciplinary research", Journal of Service Management, Vol. 27 No. 1, pp. 9-20.

Grönroos, C. (2008), "Service logic revisited: who creates value? And who co-creates?", European Business Review, Vol. 20 No. 4, pp. 298-314.

Hartley, J., Alford, J., Knies, E. and Douglas, S. (2017), “Towards an empirical research agenda for public value theory", Public Management Review, Vol. 19 No. 5, pp. 670685.

Hodgkinson, I.R. and Hughes, P. (2014), "Strategy content and public service provider performance in the UK: an alternative approach", Public Administration, Vol. 92 No. 3, pp. 707-726.

Hood, C. (1991), “A public management for all seasons?', Public Administration, Vol. 69 No. 1, pp. 3-19.

Jaakkola, E. and Hakanen, T. (2013), "Value co-creation in solution networks", Industrial Marketing Management, Vol. 42 No. 1, pp. 47-58.

Jaakkola, E., Helkkula, A. and Aarikka-Stenroos, L. (2015), "Service experience co-creation: conceptualization, implications, and future research directions", Journal of Service Management, Vol. 26 No. 2, pp. 182-205.

Johnston, R., Brignall, S., and Fitzgerald, L. (2002), "Good enough' performance measurement: A trade-off between activity and action", The Journal of the Operational Research Society, Vol. 53 No. 3, pp. 256-262.

Johnston, R. and Clark, G. (2008), Service Operations Management, FT/Prentice Hall, Harlow.

Lane, J. (2000), New Public Management, Routledge, London. 
Lusch, R.F. and Nambisan, S. (2015), "Service innovation: A service-dominant logic perspective", MIS Quarterly, Vol. 39 No. 1, pp. 155-175.

Mettler, S. (2007), Soldiers to Citizens: The G.I. Bill and the Making of the Greatest Generation, Oxford University Press, New York.

Micheli, P. and Neely, A. (2010), "Performance measurement in the public sector in England: Searching for the golden thread”, Public Administration Review, Vol. 70 No. 4, pp. 591-600.

Mitrophanous, E. (1997), “Soft positivism”, Oxford Journal of Legal Studies, Vol. 17 No. 4, pp. 621-641.

Moore, M. H. (1995), Creating Public Value: Strategic Management in Government, Harvard University Press, Boston.

Moxham, C. (2013), "Measuring up: Examining the potential for voluntary sector performance measurement to improve public service delivery", Public Money \& Management, Vol. 33 No. 3, pp. 193-200.

Ng, I.C., Maull, R., and Yip, N. (2009), “Outcome-based contracts as a driver for systems thinking and service-dominant logic in service science: Evidence from the defence industry”, European Management Journal, Vol. 27 No. 6, pp. 377-387.

Osborne, S.P., Radnor, Z. and Nasi, G. (2013), “A new theory for public service management? Toward a (public) service-dominant approach", The American Review of Public Administration, Vol. 43 No. 2, pp. 135-158.

Osborne, S.P. (2010), “The (new) public governance: A suitable case for treatment?”, in Osborne, S.P. (ed.) The New Public Governance? Emerging Perspectives on the Theory and Practice of Public Governance, Routledge, London, pp. 1-16.

Osborne, S.P., Radnor, Z., Kinder, T. and Vidal, I. (2015), “The SERVICE Framework: A Public-service-dominant Approach to Sustainable Public Services", British Journal of Management, Vol. 26 No. 3, pp. 424-438.

OECD (2017), Health Spending (indicator). Doi: 10.1787/8643de7e-en (Accessed on 15 May 2017).

Pareigis, J., Echeverri, P. and Edvardsson, B. (2012), "Exploring internal mechanisms forming customer servicescape experiences”, Journal of Service Management, Vol. 23 No. 5, pp. 677-695.

Pinho, N., Beirão, G., Patrício, L. and Fisk, R.P. (2014), “Understanding value co-creation in complex services with many actors", Journal of Service Management, Vol. 25 No. 4, pp. 470-493. 
Pollitt, C. and Bouckaert, G. (2011), Public Management Reform: A Comparative Analysis New Public Management, Governance, and the Neo-Weberian State, Oxford University Press, US.

Radnor, Z.J. and Noke, H. (2013), "Conceptualising and contextualising public sector operations management”, Production Planning \& Control, Vol. 24 No. 10-11, pp. 867-876.

Radnor, Z. and Osborne, S.P. (2013), “Lean: a failed theory for public services?”, Public Management Review, Vol. 15 No. 2, pp. 265-287.

Radnor, Z., Osborne, S.P., Kinder, T. and Mutton, J. (2014), “Operationalizing co-production in public services delivery: The contribution of service blueprinting", Public Management Review, Vol. 16 No. 3, pp. 402-423.

Ravishankar, M.N., Pan, S.L. and Leidner, D. E. (2011), "Examining the strategic alignment and implementation success of a KMS: A subculture-based multilevel analysis", Information Systems Research, Vol. 22 No. 1, pp. 39-59.

Soss, J., Fording, R. and Schram, S.F. (2011), “The organization of discipline: From performance management to perversity and punishment", Journal of Public Administration Research and Theory, Vol. 21 No. 2, pp. 203-232.

Tax, S.S., McCutcheon, D. and Wilkinson, I.F. (2013), “The service delivery network (SDN): A customer-centric perspective of the customer journey", Journal of Service Research, Vol. 16 No. 4, pp. 454-470.

Van de Walle, S. (2016), "When public services fail: A research agenda on public service failure", Journal of Service Management, Vol. 27 No. 5, pp.831-846.

Vargo, S.L. and Lusch, R.F. (2008), "Service-dominant logic: Continuing the evolution", Journal of the Academy of Marketing Science, Vol. 36 No. 1, pp. 1-10.

Vargo, S.L. and Lusch, R.F. (2004), "Evolving to a new dominant logic for marketing", Journal of Marketing, Vol. 68 No. 1, pp. 1-17.

Verleye, K., Jaakkola, E., Hodgkinson, I.R., Jun, G.T., Odekerken-Schröder, G. and Quist, J. (2017), "What causes imbalance in complex service networks? Evidence from a public health service", Journal of Service Management, Vol. 28 No. 1, pp. 34-56. 
Figure 1. The Public Service Network Framework (PSNF)

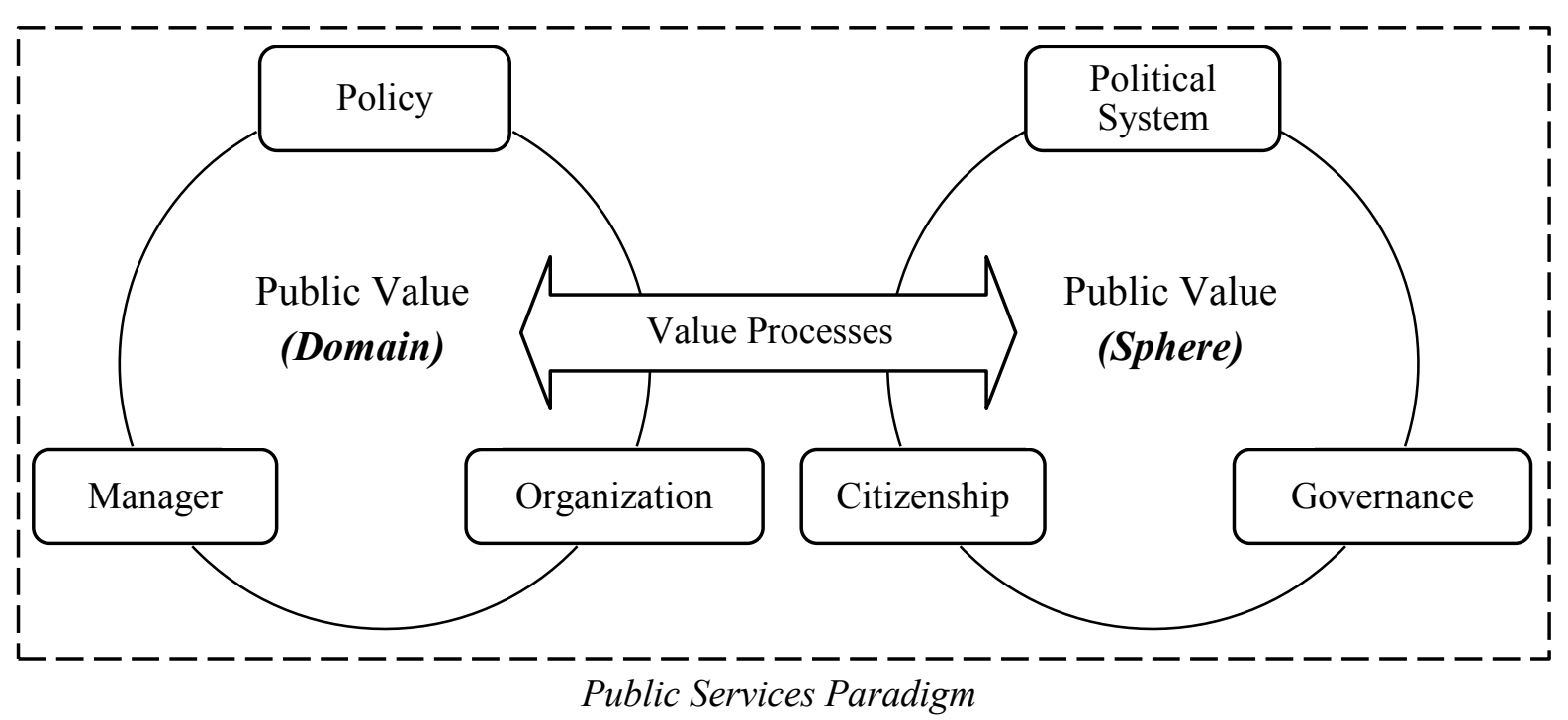


Table I. Future directions for public service management research

\begin{tabular}{|c|c|}
\hline $\begin{array}{l}\text { Public service management } \\
\text { shortcomings }\end{array}$ & Directions for future research \\
\hline $\begin{array}{l}\text { 1. There is a need to capture the whole- } \\
\text { service value network and value creation } \\
\text { processes therein across two levels: domain } \\
\text { (terms raised include manager, organization, } \\
\text { and policy) and sphere (terms raised include } \\
\text { citizenship, governance, and democracy). } \\
\text { Understanding of how value is created at } \\
\text { these levels is lacking. }\end{array}$ & $\begin{array}{l}\text { How is public value shaped in emerging economies } \\
\text { under different landscapes (e.g., political systems, } \\
\text { governance, citizenship, policy, etc.)? } \\
\text { Which public services strengthen the public services } \\
\text { paradigm, and in what ways, and which do not? } \\
\text { How should the usefulness of approaches to mapping } \\
\text { the public value creation (or destruction) process and } \\
\text { its effects on service provision and service recipients } \\
\text { be developed and tested? }\end{array}$ \\
\hline $\begin{array}{l}\text { 2. Current measurement of service } \\
\text { evaluation, which has focused on efficiency }\end{array}$ & $\begin{array}{l}\text { What should an integrated PSDL approach to public } \\
\text { value, across the domain and sphere levels look like? }\end{array}$ \\
\hline $\begin{array}{l}\text { and effectiveness, has held the field back } \\
\text { from being able to explore the actual } \\
\text { relevance and usefulness of PSDL. Public } \\
\text { service evaluation must be much broader to }\end{array}$ & $\begin{array}{l}\text { Which service evaluation frameworks from the service } \\
\text { management field will be valuable in highlighting the } \\
\text { impact of partnership working and of co-production on } \\
\text { different aspects of value? }\end{array}$ \\
\hline
\end{tabular}
account for neglected outcome dimensions.

3. To capture how public value emerges from different sources, including cross-sector collaboration and citizen engagement, the role of public managers and government to orchestrate value needs further investigation. This requires a move away from GDL to PSDL and the accumulation of empirical evidence.

4. Value creation is more cyclic than linear, i.e., public need drives policy, which in turn results in public service interventions that create value and address public need, and so on. It is, therefore, necessary to explore the cyclic nature of public value creation and that includes actors in the wider value creation process.
As an expected value process, why has it been so hard to achieve cost-effective collaboration in public services, which appears to have become commonplace in the private sector?

$>$ How should foci be integrated within a broader services paradigm that emphasizes both the governance of inter-organizational relationships and the efficacy of public service delivery systems, rather than discrete public service organizations?

How can we assess more convincingly value processes (incl. co-production, partnership, and intraorganizational management) within a public services paradigm?

$>$ To what extent can government deliver dialogue, and catalyze and respond to active citizenship in pursuit of what the public values and what is good for the public? 